\title{
CHANGES IN THE CONTENT OF PHENOLIC COMPOUNDS IN HONEY AFTER SPRAY DRYING
}

\author{
Anete Ķeḳe ${ }^{\#}$ and Ingmārs Cinkmanis \\ Faculty of Food Technology, Latvia University of Life Sciences and Technologies, 2 Lielā Str., Jelgava, LV-3001, LATVIA \\ \# Corresponding author, anete.keke@1lu.lv
}

Communicated by Sandra Muižniece-Brasava

\begin{abstract}
Honey contains several phenolic compounds and is a natural source of antioxidants. The use of honey is limited in the food industry, because of its high viscosity and tendency to spontaneously crystallise. Powdered honey could be an innovative alternative and would expand the application of honey in the industry. The aim of the study was to determine changes in the concentrations of individual phenolic compounds during spray drying of honey by the high-performance liquid chromatography method. The phenolic compounds in both samples were detected by a Shimadzu LC-20 Prominence liquid chromatograph using a DAD detector. Ten phenolic compounds in the liquid honey were detected. The concentration of identified phenolic compounds ranged from 1 to $190 \mu \mathrm{g} \cdot 100 \mathrm{~g}^{-1}$ dry matter. The obtained results of the spray-dried honey sample showed that there were decrease in the concentration of polyphenols. Phenolic compounds such as syringic acid and ferulic acid were not detected in the spray-dried honey sample.
\end{abstract}

Keywords: honey powder, spray drying, phenolic compounds, high-performance liquid chromatography.

Honey is a naturally sweet food product, which consists of more than 180 different compounds (Da Silva et al., 2016). The main components of honey are carbohydrates, mostly fructose and glucose. Besides these monosaccharides, a wide range of minor constituents such as enzymes, organic acids, proteins, phenolic compounds, and others are present in honey (Suárez-Luque et al., 2002; Ciulu et al., 2008; León-Ruiz et al., 2011; Khan et al., 2018). In spite of their lower amounts, phenolic compounds have a significant role in human health due to their antioxidant, anti-inflammatory, and antibacterial properties (Pyrzynska and Biesaga, 2009). Phenolic compounds or polyphenols are plant-derived secondary metabolites, which have at least 8000 different known structures (Bravo, 1998). The honey polyphenols represent two large groups - phenolic acids and flavonoids (Estevinho et al., 2008). The qualitative and quantitative composition of phenolic compounds depends on many aspects such as botanical and geographical origin, climate, and seasonal factors (Kropf et al., 2010; Karabagias et al., 2014; Ciulu et al., 2016).

Honey, a natural source of polyphenols, is mostly used as a sugar substitute due to its sweet taste. As a highly nutritious product, honey could be used more for other industrial ap- plications. Honey's high viscosity and density, and its tendency to crystallize, which is a natural process due to the high concentration of sugars, affect the applicability of the product (Tappi et al., 2021). The application of honey could be increased by obtaining powdered honey (Kılınç and Demir, 2017; Tomczyk et al., 2020). Obtaining powdered honey can be carried out by using different drying techniques such as vacuum drying, spray drying, and microwave-vacuum drying (Cui et al., 2008; Nurhadi et al., 2012; Jedlińska et al., 2019; Mutlu et al., 2020). Due to its cost-effectiveness, spray drying is one of the most favourable dehydration methods to produce food products in powdered form (Bansal et al., 2014; Zorić et al., 2017; Siacor et al., 2020).

High temperatures are involved to obtain spray-dried products, which can negatively affect heat sensitive compounds like polyphenols and change the quality of product. The aim of the study was to determine changes in the concentrations of individual phenolic compounds in spray dried and liquid honey, using the high-performance liquid chromatography (HPLC) method.

Chemicals. All used phenolic compound standards and solvents were HPLC grade. Glacial acetic acid, vanillin, rutin 
hydrate, syringic acid, gallic acid, 2-hydroxycinnamic acid, trans-cinnamic acid, $p$-coumaric acid, chlorogenic acid hemihydrate, sinapic acid, (-)-epicatechin, (+)-catechin hydrate, caffeic acid, 4-hydroxybenzoic acid were purchased from Sigma Aldrich (St. Louis, MO). 3,5-dihydroxybenzoic acid, quercetin dihydrate, homovanillic acid, 4-hydroxy-3methoxybenzoic acid were from Acros Organics (New Jersey, USA ). Ferulic acid was purchased from Fluka (Charlotte, USA). Kaempferol was purchased from Cayman Chemical Company (Michigan, USA). Luteolin was from Alfa Aesar (Karlsruhe, Germany). Methanol was from Sharlab, S.L (Barcelona, Spain).

Sample. A multifloral honey sample was supplied by a beekeeper in southern Latvia. The harvest year of honey was 2018. The supplied honey was stored in a glass jar at room temperature in the dark until further experiments.

Honey solution preparation and spray drying. Honey was mixed with deionised water and maltodextrin (STARDRI® 10 NG, TATE \& LYLE) to obtain a 20\% (w/w) solution. The ratio of honey and maltodextrin in the prepared solution was 1:2. The honey and maltodextrin solution was spray-dried using a BÜCHI mini spray dryer B-290 (Labortechnik AG, Switzerland). The prepared solution was spray-dried under the following conditions: sample speed rate $15 \mathrm{ml} \cdot \mathrm{min}^{-1}$, and inlet and outlet air temperatures $180{ }^{\circ} \mathrm{C}$ and $80{ }^{\circ} \mathrm{C}$, respectively (Samborska et al., 2015). The obtained powder was collected in polyethylene bags and stored at room temperature in a dark and dry place until further analysis.

Determination of individual phenolic compounds. $1.00 \pm$ $0.01 \mathrm{~g}$ of liquid honey was dissolved in $7.5 \mathrm{ml}$ of $70 \%$ ethanol solution, homogenised, and centrifuged (Pro-Research, Centurion Scientific Ltd.) for five minutes at $10000 \mathrm{rpm}$. A sample of $3.00 \pm 0.01 \mathrm{~g}$ of the obtained honey powder was prepared as described for liquid honey. The centrifugates of both samples were used for the analysis. A Shimadzu LC-20 Prominence liquid chromatograph (Shimadzu USA Manufacturing Inc, Canby, USA) with a Shimadzu DAD SPD-M20A detector, and an analytical column YMC C18 $(4.6 \mathrm{~mm} \times 250 \mathrm{~mm}$ I.D., particle size $5 \mu \mathrm{m})$ were used for the analysis. The chromatographic analysis was performed under gradient conditions. The detection of phenolic compounds were performed as described previously (Priecina et al., 2018).

The identification of phenolic compounds in the samples was carried out by comparing the retention times of the standards at $278 \mathrm{~nm}$ wavelength. The calibration curves of the standards were used for the quantitative determination of the detected phenolic compounds in the samples. Detection and identification of phenolic compounds were done in triplicate. The obtained results were expressed as mean \pm standard deviation. A significance level $p<0.05$ was considered to indicate statistically significant differences.

In this study, powdered honey was obtained by spray drying technique. This drying method is popular among food sci-
Table 1. Phenolic profile of analysed liquid and spray-dried honey samples

\begin{tabular}{l|c|c}
\hline \multirow{2}{*}{ Compound } & \multicolumn{2}{|c}{$\begin{array}{c}\text { Concentration, } \mu \mathrm{g} \cdot 100 \mathrm{~g}^{-1} \text { dry matte } \\
\text { SD }\end{array}$} \\
\cline { 2 - 3 } & liquid honey & spray-dried hon \\
\hline Hydroxybenzoic acids & $190 \pm 4$ & $180 \pm 5$ \\
$\quad$ Gallic acid & $1 \pm 0.3$ & $\mathrm{ND}$ \\
$\quad$ Syringic acid & & \\
Hydroxycinnamic acids & $149 \pm 5$ & $136 \pm 3$ \\
$\quad$-coumaric acid & $1 \pm 0.3$ & $\mathrm{ND}$ \\
Ferulic acid & $31 \pm 4$ & $25 \pm 3$ \\
2-hydroxycinnamic acid & $8 \pm 0.2$ & $4 \pm 2$ \\
$\quad$ Trans(3)-hydroxycinnamic acid & & \\
Flavonoids & $170 \pm 9$ & $153 \pm 5$ \\
$\quad$ Rutin & $3 \pm 0.4$ & $1 \pm 0.4$ \\
Quercetin & $5 \pm 0.2$ & $2 \pm 0.2$ \\
$\quad$ Luteolin & & \\
Phenolic aldehyde & $7 \pm 2$ & $4 \pm 3$ \\
$\quad$ Vanillin & & \\
\hline
\end{tabular}

ND, standard deviation; ND, not detected

entists to obtain powdered honey (Samborska et al., 2015; Samborska, 2019). Maltodextrin was used as a carrier to properly perform the drying process. The moisture content of the spray-dried honey sample was $4.8 \%$ (Keke and Cinkmanis, 2020). Overall, ten phenolic compounds were detected in the liquid honey sample. The obtained data are shown in Table 1. Six of the detected polyphenols belong to phenolic acids. Gallic acid was the predominant phenolic acid found in the sample. The gallic acid concentration was $190 \pm 4 \mu \mathrm{g} \cdot 100 \mathrm{~g}^{-1}$ dry matter. $p$-Coumaric acid was the predominant hydroxycinnamic acid found in liquid honey. Its concentration was $149 \pm 5 \mu \mathrm{g} \cdot 100 \mathrm{~g}^{-1}$ dry matter. Syringic acid and ferulic acid both were detected in very low concentration: $1 \pm 0.3 \mu \mathrm{g} \cdot 100 \mathrm{~g}^{-1}$ dry matter. Flavonoids rutin, quercetin and luteolin were detected in the liquid honey sample. Their concentration ranged from 3 to 170 $\mu \mathrm{g} \cdot 100 \mathrm{~g}^{-1}$ (Table 1). Rutin was the predominant flavonoid in liquid and spray-dried samples. Vanillin was detected and quantified. Concentration of vanillin in the liquid honey was $7 \pm 2 \mu \mathrm{g} \cdot 100 \mathrm{~g}^{-1}$ dry matter. Polyphenol composition and quantitative concentration vary depending on their floral sources and geographic origin. This information can be used for honey authentication (Karabagias et al., 2014; Cheung et al., 2019).

The detected phenolic compounds had lower concentration in the spray-dried honey (Table 1). The reduction in polyphenol concentration was not significant $(p>0.05)$. The concentration of gallic acid in the honey powder was $180 \pm 5 \mu \mathrm{g} \cdot 100 \mathrm{~g}^{-1}$ dry matter. The concentration of gallic acid decreased by approximately 5 percent. Rutin exhibited a ten percent decrease in concentration in the honey powder. Syringic acid and ferulic acid were not detected in the honey power. As a heat-demanding process, spray drying had a minor impact on the phenolic profile and concentration, according to the results. The minor impact of spray drying on the polyphenols showed that maltodextrin, which 
was used as a carrier, successfully encapsulated the bioactive compounds. Unfortunately, to the authors' knowledge, there is a lack of data on the qualitative and quantitative changes of phenolic compounds in honey during the spray drying process. A previous study (Kozłowicz et al., 2020) on phenolic compounds in honey powder obtained by spray drying showed a wide range of phenolic compounds. The authors used a different extraction technique and the samples were examined using a GC-MS, which can provide more data than HPLC alone.

In conclusion, the concentration of phenolic compounds during the dehydration process decreased. Honey powder with maintained health-promoting qualities can be obtained by spray drying. The findings demonstrated that powdered honey can be used as an antioxidant source. Further studies are needed to carry out more extensive identification of polyphenols in various honey samples, as well as a comparison of how they change after spray drying.

\section{ACKNOWLEDGMENTS}

This research was supported by the Latvia University of Life Sciences and Technologies' project "Strengthening Research Capacity in the Latvia University of Life Sciences and Technologies", Project No. 3.2-10/2019/LLU/140.

\section{REFERENCES}

Bansal, V., Sharma, H. K., Nanda, V. (2014). Optimisation of spray drying process parameters for low-fat honey-based milk powder with antioxidant activity. Int. J. Food Sci. Technol., 49 (4), 1196-1202.

https://doi.org/10.1111/ijfs.12416 (accessed 15.12.2021).

Bravo, L. (1998). Polyphenols: Chemistry, dietary sources, metabolism, and nutritional significance. Nutr. Rev., 56 (11), 317-333.

https://doi.org/10.1111/j.1753-4887.1998.tb01670.x (accessed 15.12.2021)

Cheung, Y., Meenu, M., Yu, X., Xu, B. (2019). Phenolic acids and flavonoids profiles of commercial honey from different floral sources and geographic sources. Int. J. Food Properties, 22 (1), 290-308.

https://doi.org/10.1080/10942912.2019.1579835 (accessed 15.12.2021).

Ciulu, M., Solinas, S., Floris, I., Panzanelli, A., Pilo, M. I., Piu, P. C., Spano, N., Sanna, G., Estevinho, L., Pereira, A. P., Moreira, L., Dias, L. G., Pereira, E. (2008). RP-HPLC determination of water-soluble vitamins in honey. Food Chem. Toxicol., 46 (12), 3774-3779.

https://doi.org/10.1016/j.talanta.2010.10.059 (accessed 15.12.2021).

Ciulu, M., Spano, N., Pilo, M. I., Sanna, G. (2016). Recent advances in the analysis of phenolic compounds in unifloral honeys. Molecules, 21 (4), 451 (accessed 15.12.2021)

Cui, Z. W., Sun, L. J., Chen, W., Sun, D. W. (2008). Preparation of dry honey by microwave-vacuum drying. J. Food Eng., 84 (4), 582-590. https://doi.org/10.1016/j.jfoodeng.2007.06.027 (accessed 15.12.2021).

Da Silva, P. M., Gauche, C., Gonzaga, L. V., Costa, A. C. O., Fett, R. (2016). Honey: Chemical composition, stability and authenticity. Food Chem., 196, 309-323. https://doi.org/10.1016/j.foodchem.2015.09.051 (accessed 15.12.2021).

Estevinho, L., Pereira, A. P., Moreira, L., Dias, L. G., Pereira, E. (2008). Antioxidant and antimicrobial effects of phenolic compounds extracts of Northeast Portugal honey. Food Chem. Toxicol., 46 (12), 3774-3779. https://doi.org/10.1016/j.fct.2008.09.062 (accessed 15.12.2021).
Jedlińska, A., Samborska, K., Wieczorek, A., Wiktor, A., Ostrowska-Ligęza, E., Jamróz, W., Skwarczyńska-Maj, K., Kiełczewski, D., Błażowski, Ł., Tułodziecki, M., Witrowa-Rajchert, D. (2019). The application of dehumidified air in rapeseed and honeydew honey spray drying: Process performance and powders properties considerations. J. Food Eng., 245, 80-87. https://doi.org/10.1016/j.jfoodeng.2018.10.017 (accessed 15.12.2021).

Karabagias, I. K., Vavoura, M. V., Nikolaou, C., Badeka, A. V., Kontakos, S., Kontominas, M. G. (2014). Floral authentication of Greek unifloral honeys based on the combination of phenolic compounds, physicochemical parameters and chemometrics. Food Res. Int., 62, 753-760. https://doi.org/10.1016/j.foodres.2014.04.015 (accessed 15.12.2021).

Keke, A., Cinkmanis, I. (2020). A-amylase activity in freeze-dried and spray-dried honey. In: Research for Rural Development 2020: Annual 26th International Scientific Conference Proceedings, Vol. 35, pp. 112-117 https://doi.org/10.22616/rrd.26.2020.017 (accessed 15.12.2021).

Khan, S. U., Anjum, S. I., Rahman, K., Ansari, M. J., Khan, W. U., Kamal, S., Khattak, B., Muhammad, A., Khan, H. U. (2018). Honey: Single food stuff comprises many drugs. Saudi J. Biol. Sci., 25 (2), 320-325. https://doi.org/10.1016/j.sjbs.2017.08.004 (accessed 15.12.2021).

Kılınç, M., Demir, K. M. (2017). The facilities of spray dried honey powder use as a substitute for sugar in cookie production. J. Food Health Sci., 3 (2), 67-74. https://doi.org/10.3153/JFHS17009 (accessed 15.12.2021).

Kozłowicz, K., Różyło, R., Gładyszewska, B., Matwijczuk, A., Gładyszewski, G., Chocyk, D., Samborska, K., Piekut, J., Smolewska, M. (2020). Identification of sugars and phenolic compounds in honey powders with the use of GC-MS, FTIR spectroscopy, and X-ray diffraction. Sci. Rep., 10 (1), 1-10. https://doi.org/10.1038/s41598-020-73306-7 (accessed 15.12.2021)

Kropf, U., Korošec, M., Bertoncelj, J., Ogrinc, N., Nečemer, M., Kump, P., Golob, T. (2010). Determination of the geographical origin of Slovenian black locust, lime and chestnut honey. Food Chem., 121 (3), 839-846. https://doi.org/10.1016/j.foodchem.2009.12.094 (accessed 15.12.2021).

León-Ruiz, V., Vera, S., González-Porto, A. V., Andrés, M. P. S. (2011). Vitamin $\mathrm{C}$ and sugar levels as simple markers for discriminating Spanish honey sources. J. Food Sci., 76 (3), C356-C361. https://doi.org/10.1111/j.1750-3841.2011.02041.x

Mutlu, C., Koç, A., Erbaş, M. (2020). Some physical properties and adsorption isotherms of vacuum-dried honey powder with different carrier materials. LWT - Food Sci. Technol., 134 (3), DOI:10.1016/j.1wt.2020.110166. https://doi.org/10.1016/j.1wt.2020.110166 (accessed 15.12.2021).

Priecina, L., Karklina, D., Kince, T. (2018). The impact of steam-blanching and dehydration on phenolic, organic acid composition, and total carotenoids in celery roots. Innovative Food Sci. Emerg. Technol., 49, 192-201. https://doi.org/10.1016/j.ifset.2018.01.008 (accessed 15.12.2021).

Pyrzynska, K., Biesaga, M. (2009). Analysis of phenolic acids and flavonoids in honey. Trends Anal. Chem., 28 (7), 893-902.

https://doi.org/10.1016/j.trac.2009.03.015 (accessed 15.12.2021).

Samborska, K. (2019). Powdered honey - drying methods and parameters, types of carriers and drying aids, physicochemical properties and storage stability. Trends Food Sci. Technol., 88, 133-142.

https://doi.org/10.1016/j.tifs.2019.03.019 (accessed 15.12.2021).

Samborska, K., Gajek, P., \& Kamińska-Dwórznicka, A. (2015). Spray drying of honey: The effect of drying agents on powder properties. Polish J. Food Nutri. Sci., 65 (2), 109-118.

https://doi.org/10.2478/pjfns-2013-0012

Samborska, K., Langa, E., Kamińska-Dwórznicka, A., Witrowa-Rajchert, D. (2015). The influence of sodium caseinate on the physical properties of spray-dried honey. Int. J. Food Sci. Technol., 50 (1), 256-262. https://doi.org/10.1111/ijfs.12629 (accessed 15.12.2021).

Siacor, F. D. C., Lim, K. J. A., Cabajar, A. A., Lobarbio, C. F. Y., Lacks, D. J., Taboada, E. B. (2020). Physicochemical properties of spray-dried mango phenolic compounds extracts. J. Agricult. Food Res., 2, 100048. https://doi.org/10.1016/j.jafr.2020.100048 (accessed 15.12.2021). 
Suárez-Luque, S., Mato, I., Huidobro, J. F., Simal-Lozano, J., Sancho, M. T. (2002). Rapid determination of minority organic acids in honey by high-performance liquid chromatography. J. Chromatogr. A, 955 (2), 207-214. https://doi.org/10.1016/S0021-9673(02)00248-0 (accessed 15.12.2021)

Tappi, S., Glicerina, V., Ragni, L., Dettori, A., Romani, S., Rocculi, P. (2021). Physical and structural properties of honey crystallized by static and dynamic processes. J. Food Eng., 292, 110316.

https://doi.org/10.1016/j.jfoodeng.2020.110316 (accessed 15.12.2021)
Tomczyk, M., Zaguła, G., Dżugan, M. (2020). A simple method of enrichment of honey powder with phytochemicals and its potential application in isotonic drink industry. LWT - Food Sci. Technol., 125, 109204 https://doi.org/10.1016/j.lwt.2020.109204 (accessed 15.12.2021).

Zorić, Z., Pelaić, Z., Pedisić, S., Elez Garofulić, I., Bursać Kovačević, D., Dragović-Uzelac, V. (2017). Effect of storage conditions on phenolic content and antioxidant capacity of spray dried sour cherry powder. $L W T$ Food Sci. Technol., 79, 251-259.

https://doi.org/10.1016/j.1wt.2017.01.049 (accessed 15.12.2021).

Received 22 March 2021

Accepted in the final form 12 January 2022

\section{IZMAIN̦AS FENOLU SAVIENOJUMU SATURĀ PĒC MEDUS KALTĒŠANAS IZSMIDZINĀŠANAS KALTĒ}

Medus ir dabīgs antioksidantu avots. Medus fizikālie parametri (augsta viskozitāte un blīvums) un tā tieksme spontāni kristalizēties uzglabāšanas laikā ierobežo tā plašu izmantošanu pārtikas nozarē. Pulverveida medus ir škidra medus inovatīva alternatīva, kas varētu paplašināt medus izmantošanu. Pētījuma mērķis bija noteikt izmaiņas fenolu saturā pēc medus kaltēšanas izsmidzināšanas kaltē, izmantojot augsti efektīvo šķidruma hromatogrāfiju. Individuālie fenolu savienojumi tika noteikti ar Shimadzu LC-20 Prominence šķidruma hromatogrāfu, izmantojot DAD detektoru. Škidrā medus paraugā kopumā tika noteikti desmit dažādi fenolu savienojumi. To koncentrācija paraugā variēja no 1 līdz $190 \mu \mathrm{g} \cdot 100 \mathrm{~g}^{-1}$ sausnas. Analizējot pulverveida medus paraugu, kuru ieguva ar izsmidzināšanas kaltes palīdzību, tika novērota individuālo fenolu savienojumu koncentrācijas samazināšanās. Dažas fenolskābes kā ceriņskābe un ferulskābe pulverveida medū netika noteiktas. 